\title{
Root-Knot Nematode Management in Caladium ${ }^{1}$
}

\author{
Mengyi Gu and Johan A. Desaeger ${ }^{2}$
}

Caladiums (Caladium $\times$ hortulanum) are widely planted as ornamental crops throughout the world for their large leaves with variable shapes and colorful patterns (Figure 1). They are native to the tropical regions of South and Central America. Florida has been leading the commercial production of caladium tubers in the past seven decades and provides more than $95 \%$ of the world's tuber supply (Deng 2018). Many nematodes may damage caladium roots, severely reduce the vigor and quality of plants, and lead to symptoms like leaf die back, plant stunting and tuber yield loss. In Florida, root-knot, sting, and stubby root nematodes are the most common nematodes found in caladium fields. Root-knot nematodes (Meloidogyne spp.) are considered the most important of all pests in caladiums that are grown in sand. This paper will help caladium growers understand what plant-parasitic nematodes are and current nematode management strategies for the caladium industry.

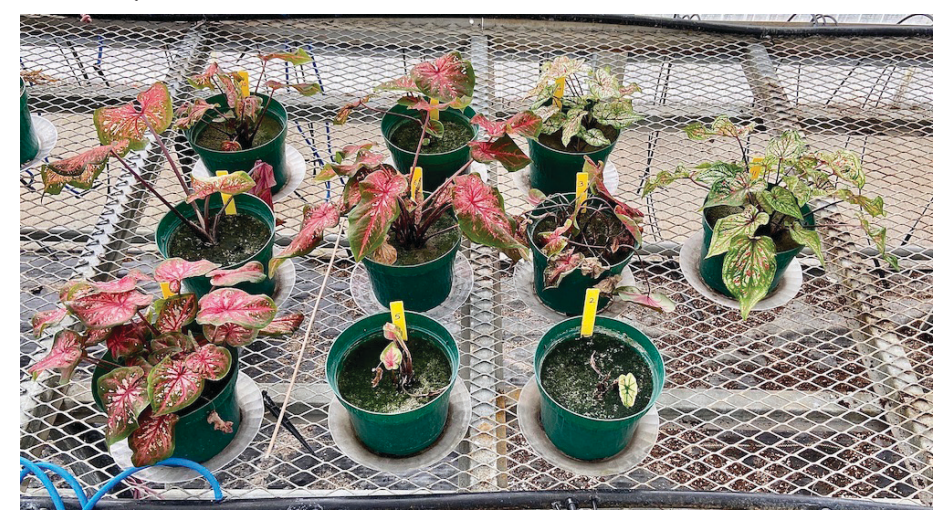

Figure 1. Different caladium varieties with variable leaf colors and patterns grown at UF/GCREC in 2020.

Credits: Mengyi Gu

\section{Biology and Life Cycle}

Plant-parasitic nematodes are microscopic, unsegmented roundworms. They feed on living plant tissues using a hollow spear, called a stylet, by puncturing and injecting digestive enzymes into the root cells and ingesting the cell contents. According to feeding habits, plant-parasitic nematodes can be divided into three groups: migratory and sedentary endoparasites, and migratory ectoparasites. Migratory endoparasitic nematodes, like lesion nematodes, may feed on the root surface, but generally they create tunnels inside the root by moving from one feeding site to another and cause root lesions; sedentary endoparasitic nematodes, such as root-knot nematodes and cyst nematodes, penetrate roots after hatching and then form a permanent feeding site inside the root or tuber where they remain for the rest of their life. Migratory ectoparasitic nematodes, like sting and stubby root nematodes, migrate through soil and feed by piercing root tissues with their stylet.

Like other nematodes, root-knot nematodes pass through six life stages: the egg, four juvenile or larval stages, and an adult stage. The first-stage juvenile (J1) forms within the egg. When hatched from the egg, the second-stage juvenile (J2) migrates toward the host and punctures and invades the vascular bundles of the host's roots and tubers (McSorley et al. 1999). Once inside the plant tissues, root-knot nematodes become sedentary and induce the formation of a permanent feeding site called a giant cell. Root tissue surrounding the giant cells enlarges and develops into a

1. This document is IN1325, one of a series of the Entomology and Nematology Department. Original publication date June 2021. Visit the EDIS website at https://edis.ifas.ufl.edu for the currently supported version of this publication.

2. Mengyi Gu, post-doctoral research associate; and Johan Desaeger, assistant professor, Entomology and Nematology Department, Gulf Coast Research and Education Center, Wimauma, FL; UF/IFAS Extension, Gainesville, FL 32611.

The Institute of Food and Agricultural Sciences (IFAS) is an Equal Opportunity Institution authorized to provide research, educational information and other services

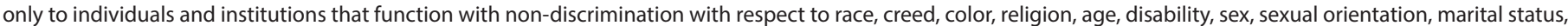

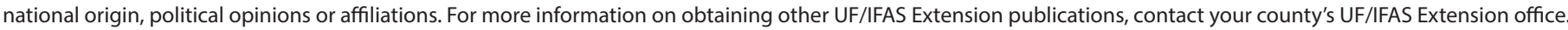
U.S. Department of Agriculture, UF/IFAS Extension Service, University of Florida, IFAS, Florida A \& M University Cooperative Extension Program, and Boards of County Commissioners Cooperating. Nick T. Place, dean for UF/IFAS Extension. 
swollen structure known as a root gall where the juvenile and later the adult remains for life. The nematode molts three times more inside the root, and then becomes either a vermiform male, or, as in most cases, a spherical female (Figure 2). The male root-knot nematode is not parasitic; it exits the root and migrates along the root surface looking for females to mate with. Males are not required for reproduction in agriculturally important Meloidogyne species such as $M$. incognita, $M$. arenaria, and $M$. javanica (Bird et al. 2009). Females lay several hundreds of eggs inside a gelatinous mass, which helps the eggs to survive between crops. The length of the root-knot nematode life cycle is temperature- and species-dependent, but in Florida is usually $3-4$ weeks.

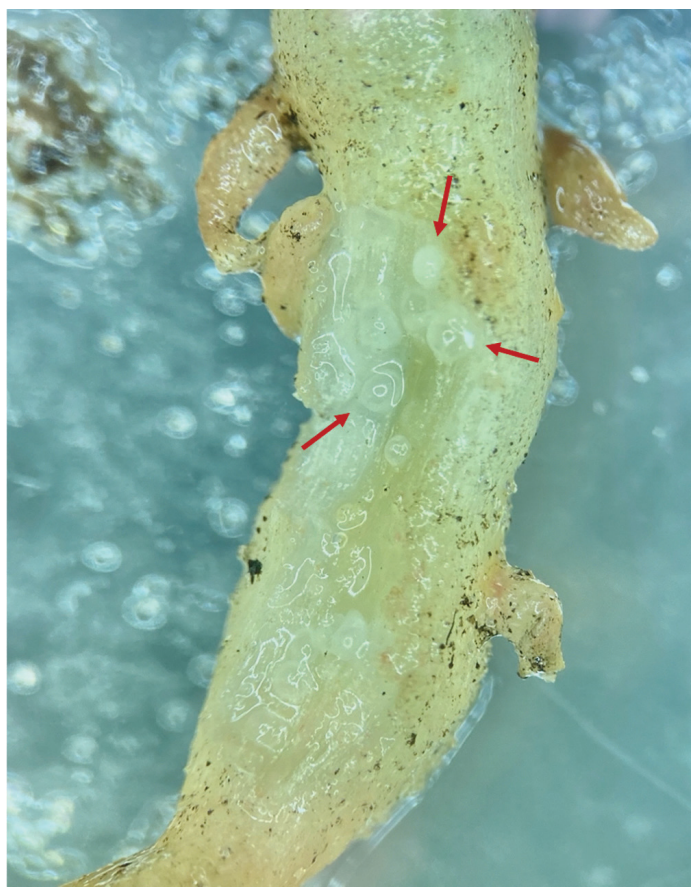

Figure 2. Female root-knot nematodes Meloidogyne arenaria buried in galled caladium root.

Credits: Mengyi Gu

\section{Economic Importance and Distribution}

Root-knot nematodes (Meloidogyne spp.) are ranked first among the top ten plant-parasitic nematode genera that have scientific and economic importance (Jones et al. 2013). Root-knot nematodes are globally distributed but cause greatest damage in the tropical and sub-tropical agricultural regions. They have broad host ranges that include many crops and weeds. Over 100 root-knot nematode species have been identified in the world, of which 16 species have been reported in Florida (Overman 1985; Lehman 2002; Church 2005; Brito et al. 2010; Pokharel et al. 2010; Han et al. 2012; Sekora et al. 2012; Brito et al. 2012; Brito et al. 2015; Desaeger 2018).
Meloidogyne javanica, M. arenaria, and M. incognita are probably the most common species in caladium fields in Florida (McSorley et al. 2004; Kokalis-Burelle et al. 2010). A greenhouse study indicated that these three species together with two more recently described species $(M$. floridensis and M. enterolobii) are all capable of reproducing on several caladium cultivars (Kokalis-Burelle et al. 2017). Caladiums can experience severe root-knot nematode damage, which results in a decline in quality and yield of tubers. Nematode-infested caladium tubers have an impact on both retail sale and replanting, which leads to economic loss.

\section{Nematode Damage Symptoms}

Caladiums are vegetatively propagated ornamentals grown from tubers, so root-knot nematodes can be transmitted in tubers from generation to generation. The growing season of caladiums lasts approximately nine months, which means severe damage can be caused as the nematodes have much time to build up to a very high level. Above ground symptoms of root-knot nematodes are irregularly distributed in the field (Figure 3), and include leaf dieback, plant stunting, wilting, and yellowing (Figure 4). Most diagnostic symptoms are found below ground and include galled roots and tubers (Figure 5), root and tuber rot (Figure 6), and corky lesions on tubers (Kokalis-Burelle et al. 2017).

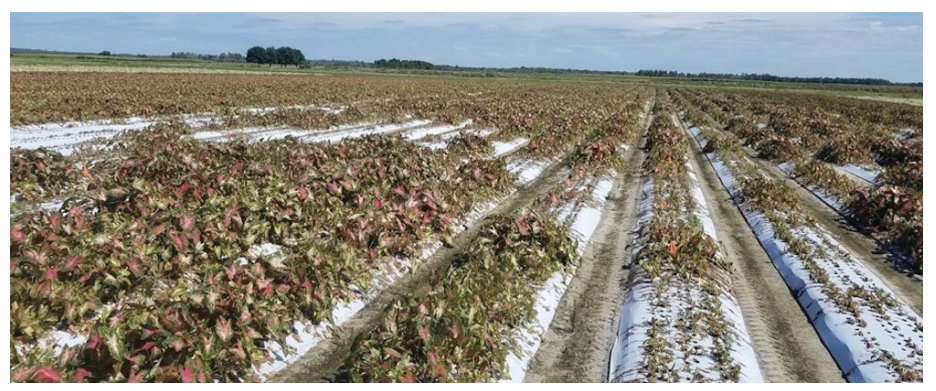

Figure 3. Irregularly distributed aboveground damage symptoms in caladium field infested with Meloidogyne arenaria, FL, October 2019. Credits: Johan Desaeger

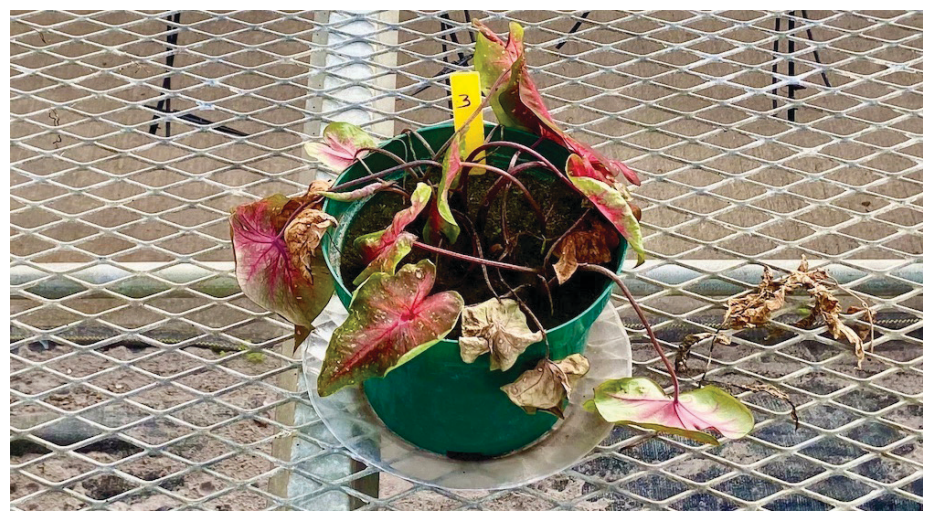

Figure 4. Wilting and yellowing symptoms caused by root-knot nematode Meloidogyne javanica on caladium variety Red Flash at UF/ GCREC in 2020.

Credits: Mengyi Gu 


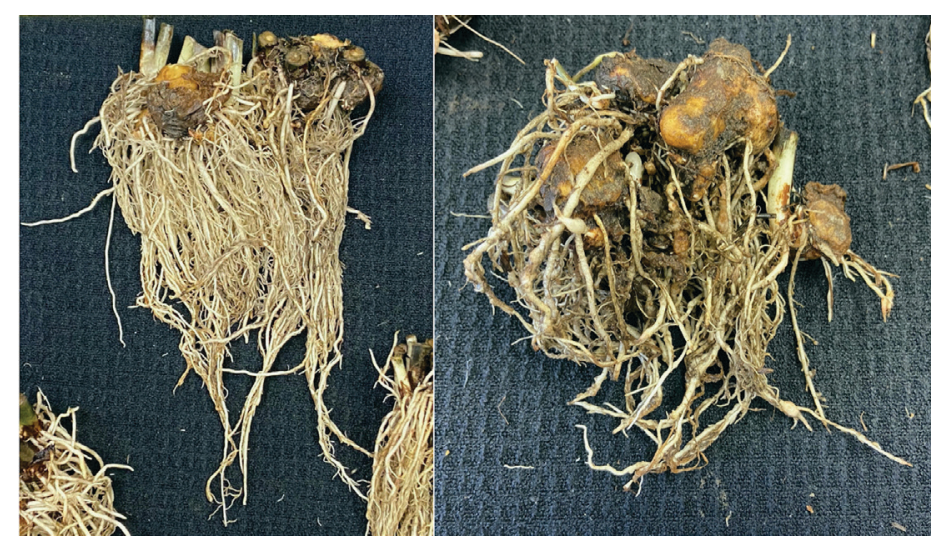

Figure 5. Galled root symptoms on caladium caused by root-knot nematode, UF/GCREC, July 2020. Left: healthy caladium roots; right: galled root symptom.

Credits: Mengyi Gu

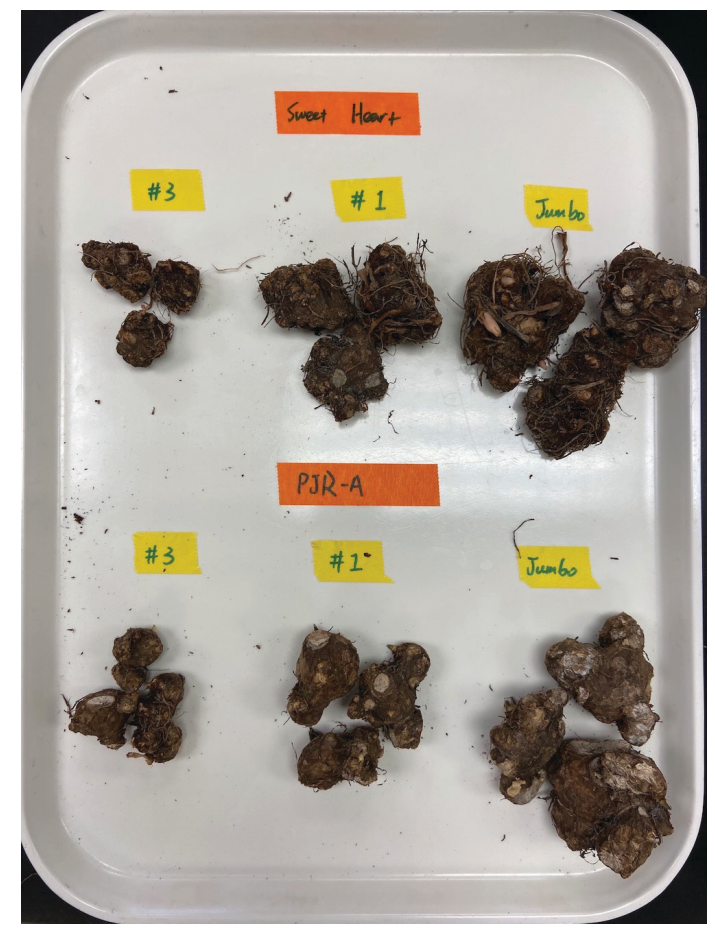

Figure 6. Caladium tubers (two cultivars Sweet Heart and Postman Joyner, each with three different tuber sizes "\#3", "\#1", and "Jumbo") infested with root-knot nematodes, UF/GCREC, July 2020. Credits: Mengyi Gu

\section{Field Diagnosis and Sampling}

In some cases, aboveground nematode symptoms are misdiagnosed because they appear similar to nutrient deficiency or damage caused by fungi like Pythium. Accurate diagnosis will prevent wasting time, money, and effort. Anytime a field has symptoms as shown in Figure 3 (Figure 3), roots should be inspected for galls and abnormal swellings. The presence of galls is almost certainly a sign of root-knot nematode. Samples can be sent for verification to the nematology lab at the UF/IFAS Gulf Coast Research and Education Center (UF/IFAS GREC) in Balm, FL, or to the UF/IFAS Nematology Assay Lab in
Gainesville, FL. Nematode diagnosis is suggested when damage symptoms are observed (verification) or by the end of crop growing season (prevention of nematode damage in next crop season). Both soil and plant samples are required to determine if plant-parasitic nematodes are the causal agents of caladium damage in the field. For diagnosis, collect both soil and plant roots and tubers from around diseased but not totally dead caladiums. For prevention, at the end of growing season caladium plants including soil and roots should be collected from symptomatic plants if they occur, or from randomly collected plants in the field if no symptoms are present. Preferably use plastic bags (not paper bags) for holding samples, and label samples with grower and crop information. When handling samples, keep samples away from direct sunlight or heat; same day and next day delivery is preferred.

\section{Nematode Management}

Traditional principles of plant disease management include avoidance, exclusion, eradication, protection, resistance, and therapy. When developing practical management strategies, these principles have to be combined with disease epidemiological principles. These have three components: reduce the initial inoculum, reduce the rate of infection, and reduce the duration of the epidemic (Anonymous 2020). These principles can be applied to nematode management strategies on caladiums.

Avoidance and Exclusion. Nematode damage can be prevented by selecting a site with no or low root-knot nematode infestation. In fields already infested with nematodes, soil fumigation is one of the most common management tactics before caladium tuber planting, which reduces the initial nematode population densities. Avoiding introduction of nematodes to the field is another important strategy to prevent nematode problems. Make sure to clean equipment before and after working in different fields. Do not plant nematode-infested caladium tubers.

Resistance. Currently no root-knot-nematode-resistant caladium cultivar is available; however, the level of nematode susceptibility is different among caladium cultivars and root-knot nematode species (McSorley et al. 2004; KokalisBurelle et al. 2017). Relatively low reproduction of southern root-knot nematode ( $M$. incognita) and guava root-knot nematode ( $M$. enterolobii) were recovered from the cultivar 'Pink Beauty' (Dover et al. 2005; Kokalis-Burelle et al. 2017). Preliminary data from UF/IFAS GCREC nematology lab indicated no root-knot-nematode-resistant cultivar has been identified yet, but caladium cultivars 'Heart and Soul', 'Sizzle', and 'Red Flash' were less damaged by the 
Javanese root-knot nematode (Meloidogyne javanica) than other cultivars evaluated.Caladium breeding programs are on-going at the University of Florida and by private growers in Florida (Figure 7).

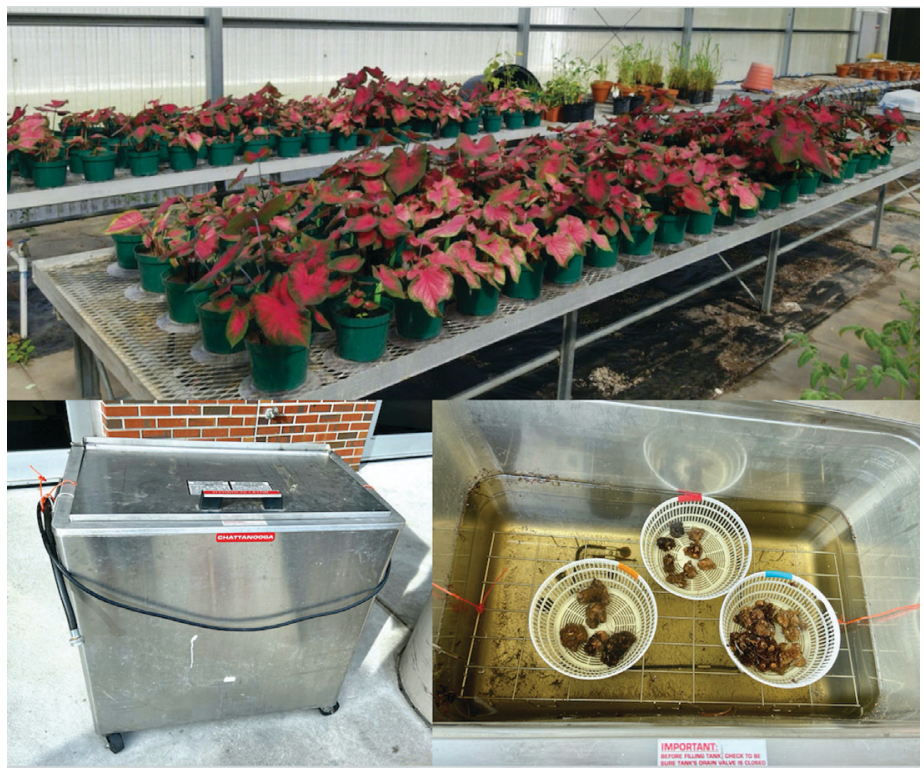

Figure 7. Greenhouse trials were conducted at the UF/GCREC from 2019-2020 to screen the potential resistant caladium cultivars. Credits: Mengyi Gu

Protection and Therapy. Pre-plant tuber treatments with nematcidal products may help reduce the nematode infection rate on caladiums, but currently no such products are available for caladium. Thermotherapy with hot water treatment (Figure 8 ) at $50^{\circ} \mathrm{C}$ for 30 minutes (Rhoades 1961; Rhoades 1964; Bricka et al. 2000) is broadly used as a pre-planting standard practice in caladium production to reduce initial nematode numbers and provide nematodefree tubers for the caladium industry. Greenhouse experiments conducted at UF/IFAS GCREC indicated that both 30 and 45 minutes of hot water exposure at $50^{\circ} \mathrm{C}$ significantly reduced reproduction of Meloidogyne arenaria on two caladium cultivars 'Sweet Heart' and 'Postman Joyner'.

Weed Control and Crop Rotation. Root-knot nematodes have a wide host range. Many weeds can be alternative hosts to Meloidogyne spp. (i.e., nutsedges). Weed removal by hand and through herbicide application can be good ways to reduce the number of nematodes. Crop rotation is not widely adopted in the caladium industry due to the long caladium tuber production season, which lasts for nine months. Cover crops that can help with root-knot nematode management are sunn hemp and sorghum-sudangrass. Both cover crops are poor hosts to most root-knot nematode populations (McSorley 1999). Sunn hemp suppresses sting nematode and stubby nematode (Wang and McSorley
2004; Braz et al. 2016); however, sorghum-sudangrass is a good host to sting and stubby root nematodes (Crow et al. 2001). For more information on nematode management with cover crops, please refer to other EDIS publications ENY059 ("Soil Organic Matter, Green Manures, and Cover Crops for Nematode Management”), ENY063 (“Cover Crops for Managing Root-Knot Nematodes"), ENY716 ("Nematode Management Using Sorghum and Its Relatives"), and ENY717 ("Management of Nematodes and Soil Fertility with Sunn Hemp Cover Crop").

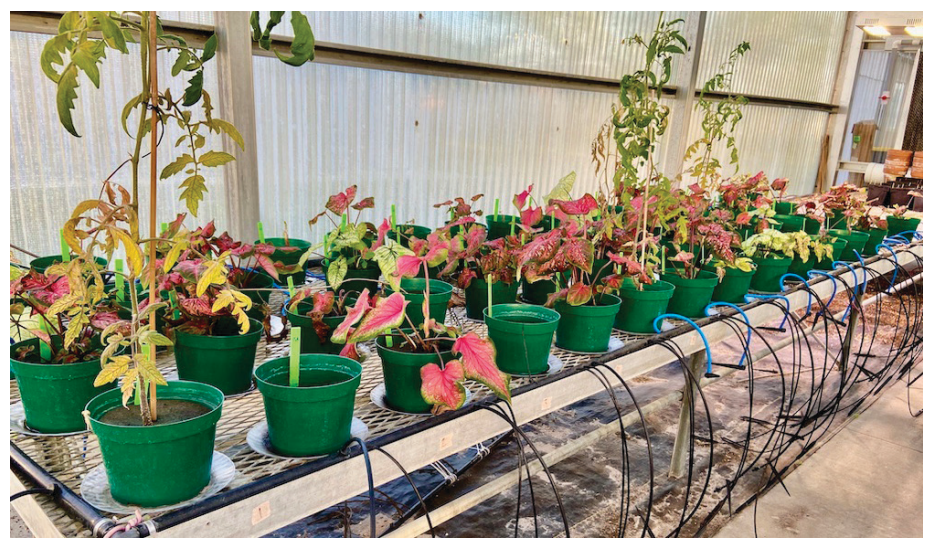

Figure 8. Hot water treatment on caladium tubers. Top: greenhouse trials were conducted at the UF/GCREC in 2020 to study the effects of different water bath exposure periods on killing root-knot nematodes in tubers of caladium cultivars; bottom left: water bath equipment; bottom right: caladium tubers with different sizes under hot water treatment.

Credits: Mengyi Gu

Soil management. Especially in sandy soils, improving the soil through regular applications of organic amendments (animal and green manures, compost, etc.) will improve soil health through stimulation of natural enemies of nematodes and may reduce the damage caused by nematodes.

Nematicides. Caladium growers typically rely on preplanting soil fumigation to reduce the initial soil nematode numbers. Quarantine and pre-shipment stocks of methyl bromide are still available to caladium growers in limited supply. Metam sodium and 1,3-dichloropropene are alternatives to methyl bromide for pre-planting nematode management in caladium. However, soil fumigation doesn't provide season-long (nine months in Caladium) nematode control. Symptoms of nematode damage typically occur and become severe from the middle to the end of growing season. "Crop destruct" applications of metam sodium following tuber harvest is a common practice with Florida caladium growers that have nematode problems. Such applications target the nematodes while they are still actively feeding, as opposed to pre-plant fumigation when most nematodes are dormant and present at greater soil depth. No post plant nematicide is currently labeled for caladium. 
Available bionematicides include live organisms such as Bacillus firmus, Pasteuria penetrans, Trichoderma spp., and Purpureocillium lilicanus and natural toxins like those from Burkholderia, azadirachtin, and thyme oil. For more information on nematicides, please refer to other EDIS publications ENY032 ("Nematode Management in Tomatoes, Peppers, and Eggplant"), ENY033 ("Non-Fumigant Nematicides Registered for Vegetable Crop Use"), ENY041 ("Movement and Toxicity of Nematicides in the Plant Root Zone") and ENY065 ("Fumigant and Non-Fumigant Nematicides Labeled for Agronomic Crops in Florida").

In summary, nematode management on caladiums cannot rely on just one method. To develop proper nematode management strategies, it is important to understand the epidemiology of plant-parasitic nematodes. There is no effective post-plant management practice if initial plant nematode population densities in soil are too high or if plant materials already have nematodes in them. The key management strategies are nematode prevention and early detection.

\section{References}

Anonymous. 2020. Plant Disease Development and Control. American Phytopathological Society (APS) website: https://www.apsnet.org/edcenter/disimpactmngmnt/topc/ EpidemiologyTemporal/Pages/ManagementStrategies.aspx

Bird, D. M., V. M. Williamson, P. Abad, J. McCarter, E. G. J. Danchin, P. Castagnone-Sereno, and C. H. Opperman. 2009. "The Genomes of Root-Knot Nematodes." Annual Review of Phytopathology 47:1333-1351.

Braz, G. B. P., R. S. Oliveira Jr., W. T. Crow, and C. A. Chase. 2016. "Susceptibility of Different Accessions of Crotalaria juncea to Belonolaimus longicaudatus." Nematropica 46:31-37.

Bricka, C., R. McSorley, and J. J. Frederick. 2000. "Effect of Hot Water Treatments on Root-Knot Nematodes and Caladium Tubers." Proceedings of the Florida State Horticultural Society 113:158-161.

Brito, J.A., H. Han, J. D. Stanley, M. Hao, and D. W. Dickson. 2012. "First Report of Laurel Oak as a Host for the Pecan Root-Knot Nematode Meloidogyne partityla in Florida." Plant Disease 97:151.

Brito, J. A., R. Kaur, R. Cetintas, J. D. Stanley, M. L. Mendes, T. O. Powers, and D. W. Dickson. 2010. "Meloidogyne spp.
Infecting Ornamental Plants in Florida." Nematropica 40:87-104.

Brito, J. A., S. A. Subbotin, H. Han, J. D. Stanley, and D. W. Dickson. 2015. "Molecular Characterization of Meloidogyne christiei Golden and Kaplan, 1986 (Nematoda, Meloidogynidae) Topotype Population Infecting Turkey Oak (Quercus laevies) in Florida." Journal of Nematology 47:169-175.

Church, G. 2005. "First Report of the Root-Knot Nematode Meloidogyne floridensis on Tomato (Lycopersicon esculentum) in Florida." Plant Disease 89:527.

Crow, W. T., D. P. Weingartner, D. W. Dickson, and R. McSorley. 2001. "Effect of Sorghum-Sudangrass and Velvetbean Cover Crops on Plant-Parasitic Nematodes Associated with Potato Production in Florida." Journal of Nematology 33:285-288.

Deng, Z. 2018. Caladium. In J. Van Huylenbroeck (ed) Ornamental Crops. Handbook of Plant Breeding, vol. 11. Springer, Cham.

Desaeger, J. A. 2018. "Meloidogyne hapla, the Northern Root-Knot Nematode, in Florida Strawberries and Associated Double-Cropped Vegetables." EDIS https://doi. org/10.32473/edis-in1224-2018

Dover, K. D., R. McSorley, and K. H. Wang. 2005. "Resistance and Tolerance of Caladium Cultivars to Meloidogyne incognita." Soil and Crop Science Society of Florida Proceedings 64:98-102.

Han, H., J. A. Brito, and D. W. Dickson. 2012. "First Report of Meloidogyne enterolobii Infecting Euphorbia punicea in Florida." Plant Disease 96:1706.

Jones, J. T., A. Haegeman, E. G. J. Danchin, H. S. Gaur, J. Helder, M. G. K. Jones, T. Kikuchi, R. Manzanilla-López, J. E. Palomares-Rius, W. M. L. Wesemael, and R. N. Perry. 2013. “Top 10 Plant-Parasitic Nematodes." Molecular Plant Pathology 14:946-961. https://doi.org/10.1111/mpp.12057

Kokalis-Burelle, N., E. N. Rosskopf, and R. D. Hartman. 2010. "Evaluation of Soil Treatments for Control of Meloidogyne arenaria in Caladium Tubers (Caladium $\times$ hortulanum) and Nematode Susceptibility of Selected Cultivars." Nematropica 40:177-189.

Kokalis-Burelle, N., J. A. Brito, and R. D. Hartman. 2017. "Susceptibility of Seven Caladium (Caladium $\times$ hortulanum) Cultivars to Meloidogyne arenaria, M. enterolobii, 
M. floridensis, M. incognita, and M. javanica." Journal of Nematology 49:457-461.

Lehman, P. S. 2002. "Phytoparasitic Nematodes Reported in Florida." Nematology Section, Bureau of Entomology, Nematology, and Plant Pathology Division of Plant Industry, Florida Department of Agriculture and Consumer Services. https://www.fdacs.gov/ezs3download/ download/25244/516160/phyotnema

McSorley, R. 1999. "Host Suitability of Potential Cover Crops for Root-Knot Nematodes." Journal of Nematology 31:619-623.

McSorley, R., J. J. Frederick, and R. J. McGovern. 1999. "Extraction of Meloidogyne incognita from Caladium Corms." Nematropica 29:245-248.

McSorley, R., K.-H. Wang, and J. J. Frederick. 2004. "Host Suitability of Caladium Varieties to Meloidogyne incognita." Nematropica 34:97-101.

Sekora, N. S., C. W. Crow, and T. Mekete. 2012. "First Report of Meloidogyne marylandi Infecting Bermudagrass in Florida." Plant Disease 96:1583.

Overman, A. J. 1985. "Root-Knot Nematodes in Gladiolus Corms.” Nematology Circular 123. https://www.fdacs.gov/ content/download/10914/file/nem123

Pokharel, R. R., G. S. Abawi, J. M. Duxbury, C. D. Smat, X. Wang, and J. A. Brito. 2010. "Variability and the Recognition of Two Races in Meloidogyne graminicola." Australasian Plant Pathology 39:326-333.

Rhoades, H. L. 1961. "Preliminary Studies on Eradication of Root-Knot in Caladium Tubers." Proceedings of the Florida State Horticultural Society 74:393-397.

Rhoades, H. L. 1964. "Effect of Hot Water Treatment of Seed Tubers and Soil Fumigation for Control of Root-Knot on Yield of Caladiums." Plant Disease Reporter 48:568-571.

Wang, K. H., and R. McSorley. 2004. "Management of Nematodes and Soil Fertility with Sunn Hemp Cover Crop." EDIS (18) https://doi.org/10.32473/edis-ng043-2004 